\title{
Measuring Success of Constitutional Reforms: Evidence from Territorial Reforms in Eight Western Democracies
}

\author{
NATHALIE BEHNKE*, BETTINA PETERSOHN**, \\ ANDREA FISCHER-HOTZEL ${ }^{* *} \&$ DOMINIC HEINZ** \\ *Department of Politics \& Political Administration, University of Konstanz, Konstanz, Germany, \\ **Institute for Political Science, Technische Universität Darmstadt, Darmstadt, Germany
}

\begin{abstract}
Studies of constitutional reforms so far have equated formal ratification with a successful reform. The paper goes beyond this narrow focus by adding substantive success as a second dimension based on two indicators: degree of agenda fulfilment and degree to which the reform contributes to solve the constitutional problem. Analysing territorial reforms in unitary or federal states, we distinguish two types of problems group and efficiency problems. The comparative analysis of formal and substantive success demonstrates that first, reforms can be at least partly successful in terms of substance, although they may have failed formally; second, fulfilling the reform agenda seems to be a necessary but not a sufficient condition for solving the constitutional problem at stake; third, cases with group problems score higher on both indicators, thus being more successful than cases with efficiency problems. Furthermore, the characteristics of the two most successful cases suggest that opportunities for participation, open dialogue and consensus building play an important role in explaining the results.
\end{abstract}

KEY WoRds: Constitutionalism, territorial reform, comparative case studies, measuring reform success

\section{Introduction}

Political theories traditionally imply that efforts to reform a constitution are more likely to fail than to succeed, no matter whether they focus on motivations of rational actors (Buchanan and Tullock, 1962), on institutional rules (Baumgartner and Jones, 1993), or on a combination of both, as in veto players' theory (Tsebelis, 2002) or actor-centred institutionalism (Scharpf, 1997). Rules of amendment usually set high 
thresholds for cross-party consensus and give veto players a particularly strong position. However, empirical studies have convincingly shown that constitutional rigidity is not a good predictor for the likelihood or frequency of constitutional reform (Lorenz, 2005). Even constitutions that are formally very rigid may be amended quite often, as is the case, for example, in Germany or Chile (Lorenz, 2010). Apparently, constitutional reforms succeed more often than it would be expected theoretically. However, theoretical as well as empirical analyses use a formal criterion ratification to establish whether or not a reform has been successful. But is this a realistic and useful operationalization of reform success? What exactly does 'success' mean when applied to a constitutional reform?

There are at least two good reasons why this question has been neglected so far. First, constitutional reforms are complex processes in which different actors have different issues at stake. Authors who have attempted to shed light on the conditions of success or failure of constitutional reforms usually enumerate factors and variables influencing reform processes that need to be studied in detail for every case (Köppl, 2007; Bußjäger and Knüpling, 2008). Second, it is far from trivial to measure the presence or absence, let alone the degree of success, of constitutional reforms. What might be a success for some, others may consider as failure. Whose perspective should be taken in evaluating reform success and is there an objective measure at all?

Thus, a shared understanding of the meaning of success as well as an analytical framework for comparative studies of constitutional reforms is still missing. In this sense, it is important to measure the success of constitutional reforms because we will be able to generate hypotheses on the determinants of success in the future only if we can establish a sound theoretical understanding of whether and to what extent reforms are successful. If we want to measure success, we need an empirical basis that allows us to compare several cases of such reform processes, but also in-depth knowledge about every individual case.

In our attempt to assess degrees and variations of reform success, we focus on cases of constitutional reforms concerning territorial institutions and arrangements in multilevel systems in federal as well as in decentralizing states. ${ }^{1}$ After a review of existing research on constitutional and federal reforms in terms of reform success we develop our measuring instrument. In order to measure the success of these constitutional reforms, we distinguish between formal and substantive success and failure. While formal success refers to the completed ratification procedure and can be determined straightforwardly, the notion of substantive success rests on a comparison of reform aspirations and results. We thus propose two indicators for the measurement of substantive success. Our first indicator takes into account the reform tasks as defined in the reform agenda, the second relates to the constitutional problems at stake. In distinguishing constitutional problems, we rely on a typology by Banting and Simeon (1985), which we elaborate further according to our research purpose. We then present our empirical results, identifying distinctive patterns of formal and substantive success. We can show that (a) the distinction of the two dimensions is, indeed, necessary as the cases investigated score very differently; (b) a high degree of agenda fulfilment seems to be a necessary but not a sufficient condition for problem solving; (c) contrary to our assumption, group problems seem to be easier to solve than efficiency 
problems; but (d) in order to explain the differences more accurately we need to consider additional variables characterizing the reform processes and situational contexts.

\section{Constitutional Reform, Territorial Reform and Success-State of the Art}

The scrutiny and analysis of processes and results of territorial reforms at constitutional level draw on insights from federalism as well as constitutionalism research. Insights from federalism research underline the general problems of constitutional reforms because the multi-level structure of federal states further complicates the difficulties present in every kind of constitutional change as they are discussed in studies on constitutional change. We, thus, rely primarily on scholarly work on different aspects of constitutional change or reform and politics.

Traditional research on constitutionalism largely neglects the questions of reform success and failure or of factors enhancing the likelihood of one or the other. Most constitutional studies, if they consider the possibility of constitutional reform at all, focus rather on other questions, such as the optimal constitutional design from a normative (Sartori, 1992; Dahl, 1996; Lutz, 2006), positive (Stern, 1984; Hesse, 1985) or economic (Cooter, 2000) point of view; the impact of institutional hurdles (Lutz, 1994; Lorenz, 2005), the importance of culture for constitutional stability (Ackerman, 1984; Häberle, 1998; Ferejohn, et al., 2001; Vorländer, 2006) or the quantitative measurement of the extent of constitutional reform (Lorenz, 2004; Busch, 2006).

In discussing constitutional change or reform, different arguments are presented answering the questions when and why a constitution is changed. From an economic perspective, on the one hand, approaches of constitutional political economy, rational choice and neo-institutionalism emphasize the opportunity structure as well as the benefits a particular institutional setting offers to rational actors. Veto player theory assumes that different actors agree on altering the constitutional status quo only if policy gains outweigh transaction costs for each of them (Tsebelis, 2002; critically Ganghof and Bräuninger, 2003). From a sociological perspective, on the other hand, the importance of constitutional stability is highlighted, with an emphasize on efficiency, equilibria or a supportive constitutional culture as stabilizing factors. In this perspective, constitutional change is brought about by any situation or event that causes inefficiency (historical approaches, e.g. Loewenstein, 1961), disequilibrium (formal neo-institutionalist approaches, e.g. Bednar, 2009), or an erosion of constitutional consensus (sociological approaches, e.g. Livingston, 1956; Vorländer, 1981). In such cases, adaptation becomes vital in order to restore a constitution's functional performance, to appease group conflicts or to reconcile the spirit of the constitution with the fundamental convictions of the members of its society.

The tension between constitutional stability and the necessary flexibility is particularly acute in multi-level systems (Behnke and Benz, 2009; see also Benz and Colino, 2011, this issue) because federal stability is even more fragile due to constant centripetal and centrifugal tendencies (Filippov et al., 2004; Bednar, 2009; Broschek, 2009). In this regard, insights about mechanisms of constitutional reform or adaptation securing the long-term constitutional stability are even more important in their application to multi-level constitutions. To be sure, federal reforms are not necessarily constitutional reforms. But, as soon as fundamental power claims are at stake in terms of 
450

reallocation of competences or resources competing interests between federal subjects can be accommodated only at constitutional level.

As opposed to issues of constitutional stability there is also an ample discussion about constitutional rigidity to account for different degrees and scope of constitutional reform (Lutz, 1994; Lorenz, 2005). This research does not investigate reform triggers, but is concerned with the chances for initiating and completing a constitutional reform, depending on the institutional hurdles specified in the usually written rules of amendment. Types of constitutional reform can then be classified according to the number of articles changed in a reform. Typically, a constitutional amendment (only one or few articles changed) is distinguished from a partial revision (larger reforms entailing connected parts of the constitution) and a total revision (the redrafting of a constitution). This or similar distinctions are used, for example, by Holmes and Sunstein (1995), Loewenstein (1961), and Busch (1999). ${ }^{2}$ Still, the number of changed articles in relation to the degree of constitutional rigidity tells us nothing about the success of reform initiatives in terms of solving constitutional problems. A more useful predictor is the degree to which constitutional changes are contested (Bryde, 1982). In Germany, for example, technical language adaptations of a large number of articles have been agreed upon by all parliamentary parties without even a debate and have been passed just like ordinary acts of legislation. Hence, amendment rules become relevant hurdles to constitutional reforms only if the issues at stake are controversial.

Another important tradition of studies at the intersection of federalism and constitutionalism research aims at theory building on the processes of constitutional reform, mostly inspired by (comparative) case studies of constitutional politics, often in a multi-level context. These studies provide a useful basis for suggesting conditions for successful reform processes. Groundbreaking are the investigations by Jon Elster (1993; 1998), although he focuses on conditions for successful constitution making, not for constitutional reform. An explicit focus on distinctive features of the reform process can be found, for example, in the works of Loewenstein (1961), Banting and Simeon (1985), Holmes and Sunstein (1995) or Schultze (2000). More recently, several contributions have even formulated provisional conjectures about the causal link between characteristics of the reform process and its result. Among others, they list actor constellations, interaction orientations and strategies, negotiation styles and situational factors (e.g. Benz, 1993; Batt, 1996; Behnke, 2009). The question of how to evaluate outcomes is discussed explicitly by Kay (2003).

The process orientation of this latter group of studies is especially valuable in highlighting that constitutional reforms are not something that take place automatically once a malfunctioning is identified. This functionalist fallacy can be noted in older treatments of constitutional law and in rational-choice approaches to the subject. In reality, however, since the identification and definition of a reform agenda are highly politicized, shaped by interested actors and defined according to the existing power distribution in a state, a perceived need for reform may be transformed into a completely different reform agenda. Even more, a successfully passed reform does not automatically reconstitute the functionality and efficiency of the political system.

One important aspect, which is neglected in almost all studies, is the question of what constitutes reform success. Almost ubiquitously, success is identified with the 
formal ratification of an amendment law, while the question of whether the constitutional problem has been solved substantively passes from view. A helpful analogy can be taken from policy studies which have dealt with similar conceptual and methodological problems in assessing policy success. Allan McConnell (2010: 39), for example, offers a realistic definition of policy success that recognizes objective criteria of success as well as interpretative ones:

A policy is successful insofar as it achieves the goals that proponents set out to achieve. However, only those supportive of the original goals are liable to perceive, with satisfaction, an outcome of policy success. Opponents are likely to perceive failure, regardless of outcomes, because they did not support the original goals.

We have arrived at a similar solution by proposing to supplement the formal dimension of success by an assessment of substantive reform results. A measure for those two dimensions is developed in the next section. Obviously, a sound assessment of reform success and its procedural and substantive conditions allows us to raise questions of optimal design of reform processes in order to maximize chances for success. The explanation of different degrees of reform success, as desirable as it may be, lies, however, beyond our ambitions for this article. Clarifying the meaning and measuring the degree of success of constitutional reforms forms a necessary first step before we venture on this task.

\section{A Measure for Reform Success}

While literature on constitutional reforms highlights the formal criterion of ratification for determining reform success, we argue that this is only one of two equally important dimensions. Obviously, if a constitutional reform law is not ratified, this is a strong argument to assume that a reform effort has failed. We call this dimension formal success. At the beginning of a constitutional reform process stands the explicit goal of proponents of the reform to have a constitutional reform law passed according to the rules of amendment. We, thus, define a reform as formally successful if a legislative act altering the constitutional status quo has been passed and ratified successfully. ${ }^{3}$ If no agreement could be reached during the negotiations or if the ratification fails at one point, the reform is considered as formally unsuccessful. ${ }^{4}$ The formal success, however, does not tell us much about the content of the reform result or the effective solution of the constitutional problem. The reform act may, for example, be passed successfully, but contain provisions on issues completely different from those which had initially been on the reform agenda. Also, it may be ratified, but never be implemented successfully; there may be groups obstructing the reform because they do not accept the result as legitimate; or the same reform topic may be taken up soon after a formally successful ratification in a new 'round' of constitutional politics, because the problems persist in spite of the new law. It may even happen that constitutional problems can be solved substantively even though the reform attempt was formally unsuccessful by means of sub-constitutional legislation, judicial sentences or bi- or multilateral agreements producing widespread consensus. 
On a second dimension we, thus, evaluate the substantive success of the reform process. The complementation of the notion of formal success by an evaluation of a reforms' substantive success allows us to draw a more complete and more differentiated picture of reform success. The concept of substantive success is, unfortunately, not as straightforward as that of formal success because there is no objective criterion to evaluate substantive success. In addition, the judgements that need necessarily be made should be justified inter-subjectively. Therefore, it is necessary to find criteria for substantive success amenable to empirical research. We assume that it is possible to assess substantive reform success by comparing the reform results with the situation at the beginning of the reform process, namely with the kind of constitutional problem that was the initial reform issue and with the agenda set initially by crucial actors. Accordingly, we formulated the two indicators of substantive success as follows:

- the degree to which the reform tasks of the initial agenda definition are fulfilled in the reform act;

- the degree to which elite actors (e.g. members of the executive, government coalition, opposition or minority leaders, representatives of sub-state units, experts and the like) in the reform process evaluate the reform as being effective to solve the constitutional problems involved. ${ }^{5}$

There is no reason why one of the indicators would be more important than the other, so we assume as a default option that both indicators contribute with equal weight to the measure of substantive success. We do not, however, use the indicators for constructing an additive index; rather the measure of substantive success remains twodimensional, consisting of two separate values, one for each indicator. A reform process, for example, can have a value 'low' on one of the indicators and 'very high' on the other. Graphically, this is quite intuitively represented in a two-dimensional issue space where all ordered pairs between (very low/very low) and (very high/very high) are conceivable. As substantive success is a complex latent variable constructed from two ordinal indicators, we can say that a reform has been substantively very successful if all or most of the tasks of the initial reform agenda have been fulfilled and if all or most relevant actors agree that the problem has been essentially solved. At the other end of the continuum, a reform is said to be substantively unsuccessful, if the reform tasks of the agenda have not been fulfilled and if the problems have not been solved. The exact place that a particular case takes in that coordinate system depends, of course, on our qualitative judgements and may be disputable in some cases. We strive, however, to make our judgements as transparent for interpersonal reconstruction as possible. ${ }^{6}$

\section{Indicator 1: Agenda Tasks Fulfilled}

The first indicator relates to the reform tasks as they are defined in the reform agenda. The definition of the reform agenda is essentially a political process in which contradicting interests struggle for dominance. In policy analysis, agenda setting is generally regarded to be a clearly distinguishable phase in the policy process, preceding the actual negotiations (De Leon, 1999). If we regard constitutional politics as a kind of 
policy, we can safely adopt this notion. According to a common conceptualization of policy theory, issues reach the political agenda when sufficiently large coalitions of interested and powerful actors (Sabatier and Jenkins-Smith, 1999) can argue convincingly that a problem exists and offer possible solutions at the same time (e.g. Cobb and Elder, 1971; Kingdon, 2003; Princen, 2007). Formulating the agenda, therefore, links the definition phase of a constitutional problem and the negotiation phase of the reform process. But it also underlines the necessity to distinguish between constitutional problem and agenda, because only certain actors have the resources or power to define the latter. Moreover, this process of agenda setting is shaped by actors' perceptions of the problem and by political strategies for reaching the desired solutions from the very beginning (Behnke, 2009: 32).

The interests of the agenda-setting actors translate into a narrow or broad agenda, depending on how many divergent reform interests are represented. Also, several interested actors can have diverging problem definitions and solution proposals, yet agree on the need for reform. In such cases, the agenda definition is likely to be formulated more broadly and in rather general terms, postponing the definition of clear-cut tasks to the negotiation phase. On the one hand, one might expect that a narrow and precise agenda is easier to fulfil because it contains less divergent interests. Furthermore, reforms with a narrow agenda comprising only single constitutional matters might be more successful because the problem-solving capacity of one process is not overstretched, as happened, for example, in Austria's last attempt at constitutional reform. On the other hand, it can conversely be argued that the prognoses for success seem to be better if the agenda is broad because it enhances chances for log-rolling and package deals. Spill-over effects of regulations can also be taken into account more systematically if the agenda comprises a diverse range of topics. Which aspect prevails is, however, hard to predict.

Especially in multi-level systems, it can happen that the agenda setter and the ratifying actor are not the same, if, for example, an agenda is defined by a sub-state unit, whereas the reform has to be ratified in national parliament. If agenda setter and ratifying actor do not coincide, the reform project is in particular need of a broad consensus that can be reached but may require concessions, compromises on topics or even the dropping of issues from the original agenda. If agenda setter and ratifying actor coincide, it can happen more easily that a tight majority gets its way and issues on the agenda are more likely included in the final reform. We can, thus, distinguish reform agendas in two respects: they can be either narrow or broad and the agenda setter and ratifying agent can coincide or differ. Concerning both distinctions, we have conjectures that the degree of agenda fulfilment will be higher or lower, but a clear prognosis cannot be made.

For empirical operationalization and in order to ensure comparability among the cases, we use a narrow definition of the term 'agenda': the official, written declarations of reform tasks. These can be, for example, (parts of) electoral manifestos, parliamentary decisions, bills, government declarations or resolutions establishing a reform commission. Such public and official declarations (be they genuine or strategic) create commitments to reform aims vis-à-vis other negotiating parties and also vis-à-vis the broader public. Even though agendas may change in the course of the reform process, the legislative act which is finally passed as a reform result will more 
often than not be linked to and judged by the initial reform task. The fact that agendas tend to change during the negotiation process (like broadening, narrowing or shifting in focus) is taken into account in our indicator. We would assume that a reform is more successful if the initial agenda is maintained effectively compared to an agenda that has shifted strongly or been distorted. For example, if issues from the original agenda are merely mentioned in the final reform act but the focus has shifted to tasks not defined in the initial agenda. ${ }^{7}$ In contrast to this, a more precise specification of reform tasks which literally 'broadens' the agenda without adding new tasks, as has been the case, for example, in Switzerland's attempt to disentangle fields of jurisdiction, ${ }^{8}$ is not counted as shift or distortion. For this reason, we say that a reform is more successful if it covers many of the reform tasks defined in the agenda than if it includes only a few or none. In order to assess the degree to which the initial agenda is covered by the final act, we compare both documents directly. We list all reform tasks mentioned in the agenda and all reform measures mentioned in the final act for this comparison (see the Appendix). 'Very low' or 'low' success on this indicator means that the final reform law contains only a few of the tasks specified in the original agenda, a 'partial' success is ascribed to those reforms where about half of the agenda tasks have been processed and 'high' for more than half. A 'very high' success rate is used if the entire or almost the entire agenda is reflected in the final reform.

In those cases that failed formally, there exists no final ratification act. In this case, we used the documented negotiation results (reports, bill proposals etc.) as relevant sources. They are equivalent to reform acts in so far as they would have been the basis for the final vote in the eventual ratification process. If the negotiation results are complemented by subsequent laws or contracts aiming at fulfilling the original reform tasks, they can have policy effects even without formal ratification.

\section{Indicator 2: Perceived Degree of Problem Solving}

The second indicator relates to the type of constitutional problem that led to the initiation of the reform process. More often than not, those problems lie at the heart of a society and cannot be solved simply by a new law. Still, a reform process might contribute more or less substantively to solve this problem. In their wellknown volume on constitutional change, Keith Banting and Richard Simeon (1985) distinguished two different types of constitutional problems: those related to modernizing administration and decision-making processes, which they call "efficiency problems" and those related to integrating underprivileged groups or minorities, which they call "demarcation disputes". They argue that efficiency problems are usually less conflictive and have, therefore, a higher likelihood of being solved, whereas demarcation disputes entail a higher level of conflict because they are potentially intractable (Banting and Simeon, 1985: 8 9; see also Schultze, 2000; Kymlicka, 2005). In the case of efficiency problems, it seems plausible that all actors involved share the same goal, i.e. the increase in efficiency, differing only in terms of the means to achieve it. Under these conditions, compromises in the form of log-rolling strategies and package deals are possible. Demarcation disputes, on the other hand, involve moral convictions, fundamental values or differences in identity and 
belonging, and a genuine solution to the problem can be conceived only by changing one group's convictions in arguments and discussion. Those disputes seem to entail a higher risk of failure as they are less likely to be solved by compromise. This dichotomy of problem types captures the essence of what lies at the heart of most constitutional disputes. However, we prefer the term 'group problems' instead of 'demarcation disputes' because of our focus on territorial reforms. Distinct groups within a society may define themselves in a number of ways, most commonly ethnically, linguistically or politically, and demand recognition or better representation in decision-making processes as a collective group. In case of territorial concentration these groups' claims for autonomy and/or for exclusive fields of jurisdiction are translated more easily into demands for a reform of the territorial structure. ${ }^{9}$

Even though efficiency problems and group problems can be distinguished analytically, in practice both types often overlap, especially in countries with heterogeneous societies. In consequence, the estimated level of conflict as well as the likelihood of success of constitutional reforms cannot be determined straightforwardly. Although the political actors involved usually frame the problem quite clearly as either an efficiency or group problem, both types of problems include conflicts over power and resources and are, thus, transformed into redistributive conflicts. The goods that are to be redistributed vary and may comprise legislative or administrative competences, fiscal or financial resources, participation rights, special recognition and group rights. For this reason, we complemented the distinction between group problems and efficiency problems by a specification of the type of goods which are to be redistributed.

The analytical distinctions between types of problems and types of redistributed goods cannot be derived straightforwardly from reform documents. Instead, we must ultimately rely on subjective ascriptions. We try, however, to ground our impressions in careful analysis of the overall constitutional situation in a country prior to the reform by means of expert interviews, expert reports and the study of secondary literature. In cases where both types of problem are present, we assess their relative importance for the initiation of the reform process. This analytical ambiguity is all the more true for any effort to assess the degree to which the problem has been solved: First, relevant actors may not even agree on a common problem definition. Second, they may evaluate a reform result very differently. Third, we cannot expect to find their sincere judgement, because public statements are always made with regard to politics. In the light of such conceptual difficulties, we decided to use the observation of unexpected comments made by relevant actors after a reform as a proxy for the degree of problem solving. ${ }^{10}$ The reason for this is quite simple. Generally, we would expect members of the government and the government party or parties to approve of the reform for which they have voted and to defend it even afterwards, while we would expect the opposition to criticize the reform and its results. If, however, we find that actors behave or argue contrary to their group affiliation (in both directions), this is a strong signal for either substantive success or failure of problem solving. Members of the pro-reform block (usually government and majority coalition or supportive societal actors) strongly criticizing the reform or even having voted against it indicate that the reform result is viewed as lacking the capacity to solve the constitutional problem. Conversely, opposition members or critical societal forces approving the reform and endorsing it indicate that the reform results indeed contributed to solving 
the constitutional problem. As a second aspect, the impression of successful problem solving is influenced strongly by the observation of whether the same problem becomes a political issue soon after the reform process has been terminated. If parties make it part of their programme, if relevant groups continuously criticize the reform results, if a new reform process is initiated concerning the same problem, then it seems obvious that the problem has not been solved substantively.

We would, thus, say that substantive problem solving is very low or low if members of parties in government vote against the reform, if strong criticism comes not only from the opposition but also from governing parties as well as experts or if new reform initiatives are expected or launched soon after the reform has been ratified. A reform is considered to contribute partially to solving the constitutional problem if we find a mixed picture of actors' behaviour, for example, several members of governing parties voting or speaking against but also members of the opposition voting or speaking in favour of the reform, if criticism is directed only towards smaller issues but not against the main aspects of the reform or if no new reform is expected but minor adaptations are demanded soon afterwards. Finally, a high degree of problem solving is attributed to those cases in which large parts of the elite beyond the governing party (coalition) endorse the reform and its results, if political actors and experts praise the reform and if no new reform is called in the near future.

\section{Selection of Cases}

We conducted our research with a sample of ten reform cases in eight Western democracies. The focus on Western democracies seemed necessary in order to have a high comparability of external variables. Among those countries, the rationale for case selection was:

- a reform of the multi-level structure of the state and/or the vertical or horizontal reallocation of rights, competences or resources;

- an explicit reform process in the sense that reform commissions were established or reform proposals were written and (most importantly) the aim was to have a constitutional reform law passed according to the rules of amendment. Implicit constitutional change where effectively the meaning and practice of the constitution are altered without changing its text (see, e.g. Benz, 2011) is taken into account only in those cases where a direct connection to explicit processes exists;

- a recent occurrence of the reform process, which we defined as not earlier than 20 years ago.

Those criteria led us to select the following reforms: Austria, Constitutional Convention (2003 05); Belgium, State Reform (2000 01); Canada, Charlottetown Accord (1992); France, Decentralization Act II (2002 03); Germany, Federalism Reform I (2003 06); Germany, Federalism Reform II (2007 09); Italy, Reform of Title V of the Constitution (2001); UK, Scotland Devolution (1998); Switzerland, Neuer Finanzausgleich (1994 2008); and UK, Wales Devolution (1998). While in all other reform processes, reform laws would allocate competences to sub-state 
units symmetrically, the devolution laws in UK led to an asymmetrical allocation. Thus, although the devolution processes in Scotland and Wales are legislative acts within the UK, they will be treated as separate processes of constitutional reform because of their distinct agendas, separate negotiations in different actors' constellations as well as separate regional referenda for final ratification. ${ }^{11}$

\section{Patterns of Reform Success}

In this section, we present and discuss the results of the coding work (see the Appendix for an overview). All ten cases under investigation were classified according to their values on the two dimensions of (a) formal success and (b) substantive success, whereby dimension (b) consists of the two indicators 'degree of agenda fulfilment' and 'perceived degree of problem solving'. The results are visualized in Figure 1, where the two axes display the indicators of the second dimension (substantive success) of agenda fulfilment ( $y$-axis) and of problem solving ( $x$-axis). The first dimension (formal success) is displayed by a star attached to the unsuccessful cases.

\section{Reform Results Between Outright Success and Complete Failure}

On the first dimension, we distinguished between formally successful and formally failed reform initiatives. Among the ten cases under investigation, Canada and Austria were formally unsuccessful because they did not pass a constitutional reform (for Austria, see Konrath, 2005). These two cases alone highlight the

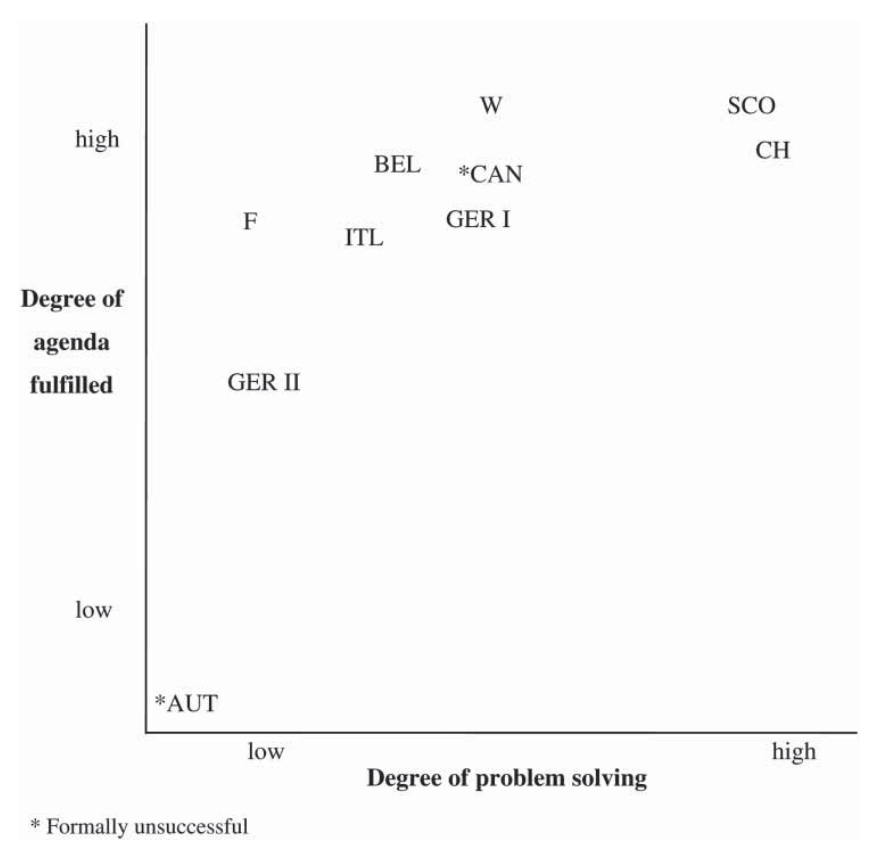

Figure 1. Location of the cases in terms of substantive success. 
importance of distinguishing the different dimensions. While Austria scores zero as a complete failure because actors were unable even to agree on a common reform proposal, Canada performs differently and reaches an intermediate degree of substantive success. There, although the reform formally failed, the negotiations resulted in a constitutional accord, which was afterwards discussed further and partially implemented by means of sub-constitutional change (Lazar, 1998; Smith, 2002). The process leading to the Charlottetown Accord, therefore, had paved the way for changing the constitutional status quo despite the failed ratification. The distinctness of the dimensions is also confirmed by the formally successful cases. Those eight cases are dispersed widely, some scoring low, some high, and some reaching even quite different scores on the two indicators. So as a first result, we can note that, in fact, formal success or failure is not necessarily associated with substantive success, in the sense that the initial agenda has been fulfilled and that constitutional problems have been solved effectively in the perception of most actors involved.

In analyzing the second dimension, we have to inspect more closely the relationship between the two indicators of substantive success. One impression is strikingly obvious: generally the cases score higher on agenda fulfilment than on problem solving. It is obviously easier to execute defined tasks even though they may not contribute to problem solving. In only two cases, Switzerland and Scotland (Mitchell, 2009), the degree of problem solving is as high as the agenda fulfilment. And we have no case below the bisecting line. We can thus infer that agenda fulfilment seems to be a necessary but not a sufficient condition for problem solving.

The highest score of overall substantive success is reached by the reform processes in Scotland and Switzerland, which are highly successful on both indicators. Switzerland had a very detailed agenda specifying measures how to reform the fiscal equalization scheme and listing fields of competences that were to be disentangled. ${ }^{12}$ For Scotland, in contrast, the formulated tasks had been rather general: establishing a Scottish Parliament and some sort of proportional representation, legislative competences for this parliament and transfer of tax-varying power (Scottish Constitutional Convention, 1995; Secretary of State for Scotland, 1997). When comparing those two agendas, it is hard to say which one is easier to fulfil. But certainly in the Swiss case, it is easier to fall short of complete achievement, because so many detailed provisions were listed.

The cases of Wales, Canada, Belgium and Germany I and, to a lesser degree, also Italy display a high level of agenda fulfilment combined with a partial degree of perceived problem solving. In terms of agenda characteristics, these cases do not have much in common. Belgium, Canada and Italy had a broadly defined agenda, aiming at a farreaching re-conceptualization of the state periphery relations, while Germany II and Wales had a rather narrow agenda focusing on specific reform issues.

The middle-ranged scope of problem solving was attributed due to several factors: first, rhetoric and behaviour of parties show a mixed picture, meaning that harsh criticism was voiced not only as expected from opposition members, but even from parties within the governing coalition, whereas some parties in opposition consented to the reform. Second, experts agreed in all these cases that successive reforms were likely to occur because of incomplete solutions of the underlying problems. Third, with the exception of the Canadian case, governing parties or party members directed 
their action towards new reform initiatives with the purpose of correcting the shortfalls of the constitutional reform.

In Belgium, the Brussels Liberals (FDF) criticized parts of the reform, especially the transfer of the legislation on the communes and provinces to the Regions, although they were part of the governing liberal alliance (Sinardet, 2010). Similarly, parts of the Welsh Labour Party voiced objections against the reform bill in the case of Wales. ${ }^{13}$ In Canada, prominent members of the Quebec Liberal Party in power in Quebec at that time joined the no-side in the referendum campaign, although the party had agreed on the Accord earlier in a special convention (Fournier and Adam, 2010). In Germany I, the federal reform could be passed only at the second attempt. Even then, although the federal government had a nominal majority of 448 MPs (the qualified majority consisted of 410 MPs), only 428 members of the Bundestag voted for the reform. And, what is more, two Länder governments opposed the reform in the second chamber (Schleswig-Holstein and Mecklenburg-Vorpommern), although their governing coalitions were formed by the same parties as the federal government (Holtschneider and Schön, 2007: 5). In Italy, the main protest came, in fact, from the oppositional centre-right camp (Bull, 2002; Vassallo, 2005 ) that had won the elections and challenged the reform in a referendum even before the law came into force. But even within the highly disparate governing centre-left coalition, many members uttered harsh criticism against the reform law. Therefore, dissatisfaction was dispersed far more broadly across the party landscape, because the impression prevailed that the search for political compromise had corrupted the substantive reform aims. This tension between an acceptable degree of agenda fulfilment, while the impression prevails that the problems have remained unresolved, is captured nicely by Andrea Morrone (2004: 250): "The reform of Title V has radically changed the original structure of the regional State ... Unresolved, however, have remained those knots which had justified its launch" (translation NB).

In contrast, opposition parties sometimes also voted in favour of a reform or expressed satisfaction with it in different ways. The votes of the then still existing Belgian opposition party Volksunie, for example, were needed for the required two-thirds majority of votes in parliamentary ratification. The party was, therefore, included in the negotiation and, in the end, half of their Members of Parliament voted for the reform which eventually caused the final break-up of the party (De Winter, 2006: 34 35). The francophone Christian Democrats (PSC), also in opposition at the federal level, abstained from voting in order to let the reform pass after they were able to negotiate an additional accord with the federal government including their demands. In Germany, the liberal party (FDP) played a pivotal role in the ratification of both reforms. In its role as opposition party, it voted against the reform in the first chamber (Bundestag). As a member of several coalition governments in the Länder, however, it voted for the reform in the second chamber (Bundesrat) where its approval was indispensable for passing the reform. This voting behaviour clearly shows that in spite of party political tactics, there was no fundamental discontent with the reform issues. In Canada, the opposition parties, the Liberals and the social-democratic NDP also approved the Charlottetown Accord, although their votes would not have been necessary in Parliament.

Despite the formal failure in the referendum, the reform in Canada ranges on a medium level of substantive success due to sub-constitutional laws and agreements implementing parts of the Accord on which the different actors had come to a consensus 
460

during the constitutional negotiations (Lazar, 1998; Russell, 2004). In the other cases with medium degree of substantive success, reforms were thought and evaluated to be incomplete by political actors and experts. In Belgium, a successive reform initiative was thought to be likely due to enhanced pressures on the federal budget, continued efficiency problems due to the existing competence distribution and the estimated gridlock in several policy fields. After the federal election of 2007, and again after that in June 2010, parties have negotiated on further reform initiatives without being able to find a consensus so far. In Wales, almost all political actors agreed that further reforms were necessary in order to create a working Legislative Assembly (Trench, 2008: 15ff.). Since the establishment of the devolved institutions, two major reforms were passed in order to make them work properly. Also, in Germany it became clear during the ratification of the first federal reform that a second reform devoted to fiscal federalism would follow immediately (Westerwelle, 2006). The reform in 2006 was praised by most politicians, but scientific experts strongly doubted the announced gain in legislative efficiency (Burkhart et al., 2008). The interpretation of the entire reform depends on whether legislative efficiency is based on the number of consent bills or on their material scope. In Italy, efforts at counter-reform from the centre-right gave vivid evidence of the low approval of the reform (Vassallo, 2005), and several implementation laws were needed to make the reform work but have not been agreed upon so far (Palermo and Woelk, 2006: 346 348; Bin, 2009).

The reform initiatives in France in 2003 and in Germany II in 2009, finally, both score low on the problem-solving dimension. In France, the agenda has formally been fulfilled to a partial to high degree (Le Lidec, 2009; Pasquier, 2009). The original agenda comprised fiscal and financial autonomy for subnational units, a constitutionally guaranteed transfer of means in case of transfers of competences and an enhanced role of the Senate as the institution representing subnational units in the legislative process. Of these issues, fiscal autonomy was taken off the agenda in the course of the reform process so that this task has to be regarded as not fulfilled. Predictably, the conservative groups in the Senate and in the National Assembly voted for the reform and the leftist groups against it, but in the debates in the National Assembly, all political groups including MPs from the governing party criticized the new financial arrangements (Congrès du Parlement, 18 mars 2003: 19 31). In the second reform in Germany, substantial parts, such as the fiscal equalization mechanism or tax autonomy for the Länder, were excluded during the negotiation process. The low degree of problem solving is due mainly to the perceived incapability of the reforms to solve the fiscal efficiency problems (Jochimsen, 2008). The chair of the first chamber (Bundestag), for example, publicly expressed his discontent with the reform despite being a member of the governing party. This perception is supported by the facts that the second reform revoked changes realized during the first and that a third reform is anticipated (Lenk, 2008).

\section{Problem Types Matter, Agendas Do Not? A Closer Look at the Results}

Now that we have arrived at a preliminary multi-dimensional measurement of success in our selected cases, we are in a position to set out to explore a few first hypotheses on the impact of relevant variables on its explanation. Therefore, we take a closer look at 
the analytical distinctions we made in the previous section concerning our two indicators. We argued that the type of constitutional problems as well as variations of the reform agenda might influence the degree of substantive success. In making use of those distinctions, we look for explanatory factors within our model of measurement. A more complete explanation of reform success can, of course, be given by using external variables describing the reform process as well as the situational and institutional context in which reforms take place. We do not inspect those external variables here, but we can make a few suggestions based on our empirical knowledge of the cases at the end of this article.

Types of problems. We had distinguished two types of constitutional problems efficiency problems and group problems. Both kinds of problems, we had noted, were transformed in the reform process into issues of redistribution with the goods to be redistributed, i.e. administrative, legislative competences or financial or fiscal resources, group rights or special protection, varying from one case to the next. In contrast to the conjecture made by Banting and Simeon (1985), we did not automatically assume that efficiency problems are solved more successfully than group problems. However, in the light of our data we now find that there might be a case for the opposite, namely that constitutional reforms dealing with group conflicts are more successful than those dealing with efficiency problems.

Six of the ten cases primarily have efficiency problems, but only half of them score high on agenda fulfilment. Cases with group problems, on the other hand, all display a relatively high level of agenda fulfilment. The impression is confirmed when analyzing the degree of problem solving. Again, cases with group problems do not perform worse than those with efficiency problems. On the contrary, cases with efficiency problems are among those with the lowest degree of problem solving whereas no case with group problems can be found in the lower section. Cases with partial or high problem-solving degrees display at least subordinate group problems, then being slightly more successful if focused on representational demands. The case of Switzerland, however, demonstrates that the existence of group problems is not a necessary requirement for a high degree of substantive success of a constitutional reform.

This result is less surprising, however, if we take into account that group problems are usually transformed into redistributive conflicts, just as efficiency problems are. In fact, as shown in Table 1, the goods which are to be redistributed are not limited to representation or group rights. Furthermore, redistributive conflicts involve legislative, administrative and tax competences. If the issues discussed are basically the same in situations of group and efficiency problems, then the difference in outcome must be caused by additional factors. It might be (but this needs to be tested) that negotiation styles vary according to the kind of constitutional problem. In accordance with conjectures in negotiation theory (Elster, 1986; Holzinger, 2001; Benz, 2007), ${ }^{14}$ one would expect that in the case of efficiency problems, bargaining might be stronger, precisely because the actors have no conflicts over goals but differ in their evaluation of the appropriate means to reach them. In group conflicts, on the other hand, all involved actors know that they tread on a heavily mined field, because contestation of redistributive claims might be interpreted as a 
Table 1. Problem types and redistributed goods

\begin{tabular}{|c|c|c|}
\hline Case & Type of problem & $\begin{array}{l}\text { Redistribution of goods and } \\
\text { resources }\end{array}$ \\
\hline $\begin{array}{l}\text { Austria Constitutional } \\
\text { Convention }(2003 \quad 05)\end{array}$ & Efficiency & $\begin{array}{l}\text { Legislative, administrative, } \\
\text { fiscal }\end{array}$ \\
\hline $\begin{array}{l}\text { Belgium State Reform } \\
\quad(2000 \text { 01) }\end{array}$ & Group problem (autonomy) & $\begin{array}{l}\text { Legislative, administrative, } \\
\text { fiscal; protection; group } \\
\text { rights }\end{array}$ \\
\hline $\begin{array}{l}\text { Canada Charlottetown } \\
\text { Accord (1992) }\end{array}$ & $\begin{array}{l}\text { (multiple) Group problem } \\
\text { (autonomy, recognition, } \\
\text { representational) }\end{array}$ & $\begin{array}{l}\text { Legislative, fiscal; special } \\
\text { protection; group rights }\end{array}$ \\
\hline $\begin{array}{l}\text { France Decentralisation } \\
\text { Acte II }\left(\begin{array}{ll}2002 & 03\end{array}\right)\end{array}$ & Efficiency & Legislative, administrative \\
\hline $\begin{array}{l}\text { Germany Federalism } \\
\text { Reform I (2003 06) }\end{array}$ & Efficiency & Legislative \\
\hline $\begin{array}{l}\text { Germany Federalism } \\
\text { Reform II (2007 09) }\end{array}$ & Efficiency & Fiscal \\
\hline $\begin{array}{l}\text { Italy Reform of Title V of } \\
\text { the Constitution (2001) }\end{array}$ & Efficiency & $\begin{array}{l}\text { Legislative, administrative, } \\
\text { fiscal }\end{array}$ \\
\hline Scotland Devolution (1998) & Group problem (representational) & $\begin{array}{l}\text { Legislative, administrative, } \\
\text { fiscal }\end{array}$ \\
\hline $\begin{array}{l}\text { Switzerland NFA (1994 } \\
\text { 2008) }\end{array}$ & Efficiency & $\begin{array}{l}\text { Legislative, administrative, } \\
\text { fiscal }\end{array}$ \\
\hline Wales Devolution (1998) & Group problem (representational) & Legislative, administrative \\
\hline
\end{tabular}

disregard of group values. This might encourage actors to adopt a rather argumentative negotiation style, leading to an overall better result.

Types of agendas. In the previous section, we had distinguished the agendas according to two criteria (Table 2): first, we assumed that the number of different topics being dealt with simultaneously in a reform process makes a difference, i.e. how broadly or narrowly the agenda is defined. And, second, we have noted that in some cases the same actors defining the agenda are the ones who ratify it, whereas in other cases,

Table 2. Agenda types

\begin{tabular}{lll}
\hline Case & Agenda & Agenda setter \\
\hline Austria Constitutional Convention (2003 05) & Broad & Ratifying \\
Belgium State Reform (2000 01) & Broad & Ratifying \\
Canada Charlottetown Accord (1992) & Broad & Not ratifying \\
France Decentralisation Acte II (2002 03) & Narrow & Ratifying \\
Germany Federalism Reform I (2003 06) & Narrow & Ratifying \\
Germany Federalism Reform II (2007 09) & Narrow & Ratifying \\
Italy Reform of Title V of the Constitution (2001) & Broad & Ratifying \\
Scotland Devolution (1998) & Narrow & Not ratifying \\
Switzerland NFA (1994 2008) & Narrow & Not ratifying \\
Wales Devolution (1998) & Narrow & Not ratifying \\
\hline
\end{tabular}


the ratifying actors include groups (sub-state governments or parliaments or the people in a popular referendum) who were excluded from agenda definition.

In six of ten cases the agenda is fulfilled to a high or very high degree Belgium, Canada, France, Scotland, Switzerland and Wales. Those six cases comprise all four possible combinations of broad or narrow agenda and ratifying or not-ratifying agenda setter. When comparing the two formally unsuccessful cases in Austria and Canada, agenda characteristics also differ. Thus, we must admit that those distinctions are not very helpful in explaining formal or substantive reform success.

Reasons for low problem solving. The rather modest overall success on the problem solving indicator compared to agenda fulfilment seems to reflect the temporary nature of the compromises found in constitutional negotiations. Constitutional reforms changing the territorial allocation of power are, thus, seemingly unable to solve problems once and for all. Even though directly after a reform a high degree of problem solving may be attributed to the results, sooner or later the same problems may pop up again. This is true for efficiency as well as for group problems, but for different reasons. In Germany, for example, two reforms succeeded each other within a short period of time and, in Belgium and Wales, further reforms were said to be necessary (Rawlings, 2003: 51ff.; Lenk, 2008; Trench, 2008: 15ff.; Deschouwer, 2009).

Reforms addressing group problems, on the one hand, can have long-term appeasing effects if a successful reform includes the establishment of procedures that allow dealing with future conflicts in a peaceful way (the best example being Canada). However, if claims for more autonomy are addressed repeatedly in constitutional reforms, thus accelerating disintegration of the state (as can be observed in Belgium), then in the long run those reforms cannot be regarded as highly successful in terms of solving the initial constitutional problem. Although one single reform can address the demands of national minorities or distinct groups successfully, the underlying constitutional problem may not be solved successfully with it.

Efficiency problems, on the other hand, relate to the functioning of the federal or unitary systems and an appropriate allocation of political, administrative and fiscal competences. A reform can be successful in the long run if it establishes a new equilibrium of tasks, rights and competences between different levels of government. But, as the notion of 'equilibrium' suggests, this will not last forever. A new power distribution will eventually become inefficient again due to changes in the relative economic or political weight of different units or due to an ideological shift.

The question of successful problem solving seems to be linked to the timely distance with which a reform process is evaluated. Problems that were solved immediately after a reform may reappear on the constitutional reform agenda after a certain time (e.g. Belgium, also Wales, Scotland or Germany). Aspects of the problem that remained unresolved immediately after the reform can be solved successively by future change, but perhaps at a sub-constitutional level (as in Canada or Italy).

Multivariate patterns. In a final step, we now combine the two problem types with the kind of redistributive goods and the agenda properties. Here, we find a few distinctive sub-patterns which suggest promising hypotheses for further research. 
Countries with group problems where regionally concentrated national, ethnic or linguistic groups pursue their interests in constitutional reform debates perform very well in finding compromises on constitutional tasks with a slightly higher degree of agenda fulfilment. Comparing our four cases with predominant group problems (Belgium, Canada, Scotland and Wales), the reforms in Scotland and Wales were more successful with their representational demands than in Canada, where different groups demanded special recognition and rights, and also than in Belgium, where group and efficiency problems overlapped. In the case of simultaneous demands of different groups, it also seems to be a more successful way to separate the processes, as was done in the UK. With regard to the degree of problem solving, cases with group problems display a similar pattern compared to the cases with efficiency problems, but reach only rarely a high degree in this category and never a low one.

In comparison, cases with efficiency problems perform not only poorer with regard to the degree of problem solving but also reach altogether slightly lower degrees with regard to agenda fulfilment. Additionally, they are more dispersed on this indicator, with the second reform in Germany being the least successful in terms of substantive success. When looking at the goods and resources that were to be redistributed in those reforms dealing with efficiency problems, different combinations can be identified. However, the two federal reforms in Germany were the only ones where the allocation of legislative competences and fiscal resources was dealt with separately. This strategic move resulted from the initially failed negotiations of the first reform in order to increase chances for at least formal success. The question whether reforming fiscal federalism detached from legistative powers has a generally a negative impact on the dimension of substantive success needs to be tested in further research by including other cases.

\section{Concluding Remarks}

The primary aim of this article was to develop a measure of constitutional reform success and to classify cases of federal constitutional reforms according to this measure. We have found that our dimensions of reform success discriminate well between the cases, and especially that substantive success can diverge widely from formal success, thus underlining the necessity of observing both dimensions separately.

We based the second dimension of substantive success on two indicators, which are in our opinion the most relevant aspects of a successful reform: the degree of agenda fulfilment and the degree of problem solving. Based on the assumption that agendas are essentially shaped by interested and powerful actors, we distinguished a broad and narrow agenda formulation and situations in which agenda setters are or are not also among the ratifying actors. These distinctions, however, had little explanatory power for differences in substantive success. Relying on a typology introduced by Banting and Simeon (1985), we distinguished efficiency and group problems. Both types of problems are transformed during the reform process into redistributive conflicts. The fact that group and efficiency problems often overlap is underlined by the kind of goods over which redistributive conflicts evolve in the case of group conflicts, material resources and fiscal competences can be as important as autonomy rights and participation. 
In methodological terms, the next step would be to test the robustness of our measure for other cases of constitutional reform. It would also be desirable to further elaborate our indicators, which we limited to ordinal measures, so that they could be used for index construction, making the measure amenable for a large- $n$ comparison.

In theoretical terms, we limited our ambition to classification of reform results and description of the ensuing patterns. An in-depth analysis of problem types, agenda types, redistributed goods and the two reform dimensions showed, for example, that cases with group problems scored higher on the substantive success dimension than cases with efficiency problems, even more so if representational demands were predominant a surprising result which calls for further investigation. Still, our indicators, which we developed for measuring the reform success, cannot completely explain the outcomes. Rather, a more complete explanation would necessarily have to rely on other structural variables, such as institutions, political culture or party systems, and situational factors, such as actors' constellations and behaviour or the reform process itself. When comparing the two most successful cases, the reforms in Switzerland (efficiency problem) and Scotland (group problem), they seem to have not so much in common with regard to the structure of the political system (federal vs. unitary), the political culture (consensual vs. competitive) or party system (multiparty vs. two dominant parties plus regionalist parties). However, if we look more closely at the processes, the Scotland act was passed by the Westminster Parliament and voted on in a regional referendum. Although not directly connected to the Scottish Constitutional Convention of the early 1990s, the devolution reform could build upon the results of this open dialogue between parties, interest organizations and civic groups. With the referendum the reform process in Scotland faced higher hurdles than the usual simple majority, whereas the constitutional reform process in Switzerland followed the usual requirement of consensus and a double majority of cantons and people in the obligatory referendum. In both cases, qualified majorities and multiple ratifying agencies made it necessary to build up broad political and societal consensus in Switzerland as formal requirement, in Scotland by accident. In this respect, any provision that makes it easier to build up such broad consensus is conducive to (formal) reform success. Such provisions can be, for example, a multiplicity of cleavages encouraging actors to establish flexible coalitions and to foster a continuous dialogue; an organization of the reform process promoting an argumentative negotiation style and making bargaining less attractive; a political culture of sequential conflict accommodation, avoiding a situation in which one group is the all-time winner and others are all-time losers.

These arrangements provide at the same time good opportunities for scoring high on the dimension of substantive success. Persistent and broad discourse, a genuine problem solving attitude, acceptance of flexible solutions seem to be relevant ingredients for an agreement on redistributive conflicts and a truly successful reform process. Fragmented societies (multi-national, multi-group, federal or even states with a very fragmented party system) or consensus democracies might be better equipped with those capacities than homogeneous societies with a competitive political pattern. 


\section{Acknowledgements}

The research presented here was conducted within a research project funded by the German Research Foundation (DFG), see http://www.constitutional-change.de. We wish to thank the anonymous reviewer for the thoughtful and elaborate comments as well as the two editors of this issue for their recommendations which contributed substantively to the improvement of our paper.

\section{Notes}

${ }^{1}$ Recent research on federalism tends to soften the dichotomy between federal and central states, intro ducing instead the notion of higher or lower levels of subnational authority (Marks et al., 2008). This differentiation is especially useful when comparing Western European reform processes, where we can find different degrees of subnational authority in formerly centrally organized states (e.g. Belgium, Spain, UK, but also France and Italy).

${ }^{2}$ For a sound terminological discussion, see Behnke and Benz (2008), for example. For our purposes here, however, we use the notions of 'reform' and 'amendment' interchangeably for deliberate altera tions according to particular rules, whereas 'change' refers to more informal ways.

${ }^{3}$ This is valid even for the British cases, where no written document has been altered, yet the devolution legislation that has been passed is agreed to have altered the constitutional status quo.

${ }^{4}$ This definition excludes the possibility of evaluating the maintenance of the status quo as successful reform, even though this may be a result very much in the interest of some of the actors involved.

${ }^{5}$ An additional possibility of evaluating reform success would be to take into account population surveys. We ruled out this option, however, because in our experience federal reforms are essentially of elite interest.

${ }^{6}$ Based on the detailed operationalization of the two indicators, we documented the rationale of our jud gements in short case descriptions for every case. Those descriptions were then discussed intensely within our research group, until we reached a high level of inter coder reliability and agreed on the assignments as they are represented in Figure 1 and in the Appendix.

To give an example: in France, the initial agenda (see Senate proposal no. 432, 22 June 2000, Le Lidec, 2009) was to constitutionally entrench fiscal autonomy of the subnational units and financial compen sation for newly assigned administrative competences as well as granting the Senate a veto for legis lation concerning subnational units. In the course of the reform process, however, the agenda broadened considerably, finally also including regulations for overseas territories and local democ racy. In that case, we trusted our experts who identified the first document as defining the 'real' agenda. Later distortions are then regarded as part of the negotiation process.

${ }^{8}$ There, the initial task as formulated in 1994 was to disentangle legislative competences and design a more efficient equalization scheme (EFD, 2004: 4). In subsequent documents these two tasks were specified by determining the number of competences (about 30) and allocating roughly half of them to a specific level of government. This is an instance of agenda specification which does not diminish the success of a reform in terms of substance.

${ }^{9}$ For a treatment of this topic, see also the contribution by Angustias Hombrado in this issue (Hombrado, 2011).

${ }^{10}$ Of course, a proxy is by definition only an approximation for the fact that was intended to be measured. However, it is a better way than not to try to assess such complex situations at all. And, finally, we based our assessments not only on the proxy, but on our own knowledge about the single cases, on expert opinions, newspaper reports and secondary literature. Taken together, proxies help to get at a much better grounded judgement of a complex situation.

${ }^{11}$ Information on the reform processes was gained in the first step by document analysis and internet research, then validated and deepened in expert interviews. A further, most important, source for getting comparable in depth information on almost all of our cases were written expert reports. For each case, we commissioned up to three country experts (academic scholars or higher civil service) with the elaboration of written reports based on an extensive questionnaire that we had prepared for 
them. Those expert reports mostly lie at the heart of the qualitative judgements we make in the follow ing sections.

${ }^{12}$ The so called 'orientation framework ' 92 ' presented by the conference of cantonal ministers of finance contained basically those measures and instruments which reappeared in all later publications (Frei burg haus, 2009).

${ }^{13}$ Interview with Gareth Hughes, 2 December 2009.

${ }^{14}$ For a discussion of the role of interaction orientations in negotiations, see also Astrid Lorenz (2011, this issue).

\section{References}

Ackerman, B. (1984), The Storrs Lectures: Discovering the Constitution, Yale Law Journal, Vol.93, pp.1013 1072.

Banting, K. G. and Simeon, R. (1985), Introduction: The Politics of Constitutional Change, in K.G. Banting and R. Simeon (eds), The Politics of Constitutional Change in Industrial Nations. Redesigning the State. London: Macmillan Press.

Batt, H. L. (1996), Die Grundgesetzreform nach der deutschen Einheit. Opdaden: Leske+Budrich.

Baumgartner, F. R. and Jones, B. D. (1993), Agendas and Instability in American Politics. Chicago: Univer sity of Chicago Press.

Bednar, J. (2009), The Robust Federation. Principles of Design. Cambridge: Cambridge University Press.

Behnke, N. (2009), Agenda Setting für Verfassungsreformen, in S. Shikano, J. Behnke and T. Bräuninger (eds), Jahrbuch für Handlungs und Entscheidungstheorie. Bd. 5: Theorien der Verfassungsreform. Wiesbaden: VS Verlag für Sozialwissenschaften.

Behnke, N. and Benz, A. (2008), Variationen föderaler Verfassungspolitik zwischen Reform und Anpas sung ein Forschungsprogramm, in Europäisches Zentrum für Föderalismus Forschung Tübingen (ed.), Jahrbuch des Föderalismus 2008. Baden Baden: Nomos Verlagsgesellschaft.

Behnke, N. and Benz, A. (2009), The Politics of Constitutional Change between Reform and Evolution, Publius, Vol.39, No.2, pp.213 240.

Benz, A. (1993), Verfassungsreform als politischer Prozess, Die Öffentliche Verwaltung, Vol.46, No.20, pp.881 889 .

Benz, A. (2007), Verhandlungen, in A. Benz, S. Lütz, U. Schimank and G. Simonis (eds), Handbuch Governance. Wiesbaden: VS Verlag für Sozialwissenschaften.

Benz, A. (2011), Das Zusammenspiel der Ebenen beim expliziten und impliziten Verfassungswandel, in Ch. Hönnige, S. Kneip and A. Lorenz (eds), Verfassungswandel im Mehrebenensystem. Wiesbaden: VS Verlag für Sozialwissenschaften.

Benz, A. and Colino, C. (2011), Constitutional Change in Federations A Framework for Analysis, Regional and Federal Studies, Vol.21, No.4 5, pp.377 402.

Bin, R. (2009), Che ha di federale il "federalismo fiscale"?, Quaderni Costituzionali, Vol.29, No.1, pp.127 130.

Broschek, J. (2009), Der kanadische Föderalismus. Eine historisch institutionalistische Analyse. Wiesbaden: VS Verlag für Sozialwissenschaften.

Bryde, B. O. (1982), Verfassungsentwicklung. Stabilität und Dynamik im Verfassungsrecht der Bundesrepu blik Deutschland. Baden Baden: Nomos Verlagsgesellschaft.

Buchanan, J. M. and Tullock, G. (1962), The Calculus of Consent. Logical Foundations of Constitutional Democracy. Ann Arbor: University of Michigan Press.

Bull, A. C. (2002), Towards a Federal State? Competing Proposals for Constitutional Revision, in P. Belluci and M. Bull (eds), Italian Politics. The Return of Berlusconi. Oxford: Berghahn Books.

Burkhart, S., Manow, P. and Ziblatt, D. (2008), A More Efficient and Accountable Federalism? An Analysis of the Consequences of Germany's 2006 Constitutional Reform, German Politics, Vol.17, No.4, pp.522 540.

Busch, A. (1999), Das oft geänderte Grundgesetz, in W. Merkel and A. Busch (eds), Demokratie in Ost und West. Festschrift für Klaus von Beyme. Frankfurt am Main: Suhrkamp Verlag.

Busch, A. (2006), Verfassungspolitik: Stabilität und permanentes Austarieren, in M.G. Schmidt and R. Zohlnhöfer (eds), Regieren in der Bundesrepublik Deutschland. Wiesbaden: VS Verlag für Sozialwissenschaften. 
Bußjäger, P. and Knüpling, F. (2008), Können Verfassungsreformen gelingen? Wien: Braumüller.

Cobb, R. W. and Elder, C. D. (1971), The Politics of Agenda Building: An Alternative Perspective for Modern Democratic Theory, The Journal of Politics, Vol.33, No.4, pp.892 915.

Congrès du Parlement (18 mars 2003), Compte Rendu Intégral, Séance du lundi 17 mars 2003, Journal Officiel de la République Française Débats Parlementaires. Available at http://www.assemblee nationale.fr/12/congres/cri/cri17032003.pdf (accessed 17 January 2011).

Cooter, R. D. (2000), The Strategic Constitution. Princeton, NJ: Princeton University Press.

Dahl, R. A. (1996), Thinking about Democratic Constitutions: Conclusions from Democratic Experience, in I. Shapiro and R. Hardin (eds), Political Order. New York: New York University Press.

De Leon, P. (1999), The Stages Approach to the Policy Process: What Has It Done? Where Is It Going? Boulder, CO: Westview Press.

Deschouwer, K. (2009), The Politics of Belgium. Governing a Divided Society. Basingstoke: Palgrave Macmillan.

De Winter, L. (2006), In Memoriam the Volksunie 1954 2001: Death by Overdose of Success, in L. De Winter, M. Gómez Reino and P. Lynch (eds), Autonomist Parties in Europe: Identity Politics and the Revival of the Territorial Cleavage. Barcelona: Institut de Ciències Politiques i Socials.

EFD, Eidgenössisches Finanzdepartment (2004), NFA Fact Sheet No. 2 "NFA im Überblick". Available at http://www.efv.admin.ch/d/downloads/finanzpolitik grundlagen/finanzausgleich/faktenblaetter/02 NFA Faktenblatt 2 berblick d.pdf (accessed 19 May 2011).

Elster, J. (1986), The Market and the Forum: Three Varieties of Political Theory, in J. Elster (ed.), Foun dations of Social Choice Theory. Cambridge: Cambridge University Press.

Elster, J. (1993), Constitution making in Eastern Europe. Rebuilding the Boat in the Open Sea, Public Administration, Vol.71, No.1 2, pp.169 217.

Elster, J. (1998), Deliberation and Constitution Making, in J. Elster (ed.), Deliberative Democracy. Cam bridge: Cambridge University Press.

Ferejohn, J., Rakove, J.N. and Riley, J. (eds) (2001), Constitutional Culture and Democratic Rule. Cam bridge: Cambridge University Press.

Filippov, M., Ordeshook, P. C. and Shvetsova, O. (2004), Designing Federalism. A Theory of Self Sustain able Federal Institutions. Cambridge: Cambridge University Press.

Fournier, M. and Adam, M. A. (2010), Expertise on 'Canada/Charlottetown Accord' for the Research Project 'Patterns of Constitutional Reform Concerning Federal Structures, unpublished manuscript, Institute for Political Science at the Technische Universität Darmstadt.

Freiburghaus, D. (2009), Expertise on 'Switzerland/Neuer Finanzausgleich' for the Research Project 'Pat terns of Constitutional Reform Concerning Federal Structures', unpublished manuscript, Institute for Political Science at the Technische Universität Darmstadt.

Ganghof, S. and Bräuninger, T. (2003), Government Status and Legislative Behavior Partisan Veto Players in Australia, Denmark, Finland and Germany. Köln: MPIfG Working Paper 03/11. Available at http:// www.mpifg.de/pu/workpap/wp03 11/wp03 11.pdf (accessed 19 May 2011).

Häberle, P. (1998), Verfassungslehre als Kulturwissenschaft. Berlin: Duncker \& Humblot.

Hesse, K. (1985), Grundzüge des Verfassungsrechts der Bundesrepublik Deutschland. Heidelberg: C.F. Müller.

Holmes, S. and Sunstein, C. R. (1995), The Politics of Constitutional Revision in Eastern Europe, in S. Levin son (ed.), Responding To Imperfection The Theory of Constitutional Amendement. Princeton, NJ: Princeton University Press.

Holtschneider, R. and Schön, W. (eds) (2007), Die Reform des Bundesstaates. Baden Baden: Nomos Verlagsgesellschaft.

Holzinger, K. (2001), Wie lassen sich empirische Verhandlungsergebnisse erklären? Politische Vierteljah resschrift, Vol.42, No.1, pp.104 111.

Hombrado, A. (2011), Learning to Catch the Wave? Regional Demands for Constitutional Change in Contexts of Asymmetrical Arrangements, Regional and Federal Studies, Vol.21, No.4 5, pp.475 497.

Jochimsen, B. (2008), Fiscal Federalism in Germany: Problems, Proposals and Chances for Fundamental Reform, German Politics, Vol.17, No.4, pp.541 558.

Kay, A. (2003), Evaluating Devolution in Wales, Political Studies, Vol.51, No.1, pp.51 66.

Kingdon, J. (2003), Agendas, Alternatives, and Public Policy. New York, NY: Longman. 
Konrath, C. (2005), Dann bleibt es eben so: Föderalismus und Kompetenzverteilung als Themen des Österreich Konvents, Österreichische Zeitschrift für Politikwissenschaft, Vol.34, No.4, pp.351 366.

Köppl, S. (2007), Zur vergleichenden Analyse von Verfassungsreformprozessen. Konzeptionelle Überlegun gen, in K.D. Wolf (ed.), Staat und Gesellschaft fähig zur Reform? Baden Baden: Nomos Verlagsgesellschaft.

Kymlicka, W. (2005), Federalism, Nationalism, and Multiculturalism, in D. Karmis and W. Norman (eds), Theories of Federalism A Reader. New York, NY: Palgrave MacMillan.

Lazar, H. (ed.). (1998), Canada: The State of the Federation 1997. Non Constitutional Renewal. Montreal, Kingston: McGill Queen's University Press.

Le Lidec, P. (2009), Expertise on 'France/La réforme constitutionelle 2003' for the Research Project 'Pat terns of Constitutional Reform Concerning Federal Structures', unpublished manuscript, Institute for Political Science at the Technische Universität Darmstadt.

Lenk, T. (2008), Föderalismusreform III Reformen sind Daueraufgabe, Wirtschaftsdienst, Vol.88, No.9, pp.572 576.

Livingston, W. S. (1956), Federalism and Constitutional Change. Oxford: Clarendon Press.

Loewenstein, K. (1961), Über Wesen, Technik und Grenzen der Verfassungsänderung. Vortrag gehalten vor der Berliner Juristischen Gesellschaft am 30. Juni 1960. Berlin: Walter De Gruyter \& Co.

Lorenz, A. (2004), Stabile Verfassungen? Konstitutionelle Reformen in Demokratien, Zeitschrift für Parla mentsfragen, Vol.35, No.3, pp.448 468.

Lorenz, A. (2005), How to Measure Constitutional Rigidity, Journal of Theoretical Politics, Vol.17, No.3, pp.339 361.

Lorenz, A. (2010), Verfassungsänderungen in föderalen und unitarischen Demokratien im Vergleich. Befunde einer empirischen Analyse für den Zeitraum von 1945 bis 2004, in J.v. Blumenthal and S. Bröchler (eds), Föderalismusreform in Deutschland. Bilanz und Perspektiven im internationalen Vergleich. Wiesbaden: VS Verlag für Sozialwissenschaften.

Lorenz, A. (2011), Constitutional Negotiations in Federal Reforms: Interests, Interaction Orientation and the Prospect of Agreement, Regional and Federal Studies, Vol.21, No.4 5, pp.403 421.

Lutz, D. S. (1994), Toward a Theory of Constitutional Amendment, American Political Science Review, Vol.88, No.2, pp.355 370.

Lutz, D. S. (2006), Principles of Constitutional Design. Cambridge: Cambridge University Press.

Marks, G., Hooghe, L. and Schakel, A. H. (2008), Patterns of Regional Authority, Regional and Federal Studies, Vol.18, No.2 3, pp.167 181.

McConnell, A. (2010), Understanding Policy Success. Rethinking Public Policy. Basingstoke: Palgrave Macmillan.

Mitchell, J. (2009), Expertise on 'United Kingdom/Scotland Devolution' for the Research Project 'Patterns of Constitutional Reform Concerning Federal Structures', unpublished manuscript, Institute for Political Science at the Technische Universität Darmstadt.

Morrone, A. (2004), Lo Stato regionale nella transizione, in S. Ceccanti and S. Vassallo (eds), Come chiudere la transizione. Cambiamento, apprendimento e adattamento nel sistema politico italiano. Bologna: Il Mulino.

Palermo, F. and Woelk, J. (2006), Pause oder Stillstand auf Italiens Weg zum Föderalismus?, in Europäisches Zentrum für Föderalismus Forschung Tübingen (ed.), Jahrbuch des Föderalismus 2006. Baden Baden: Nomos Verlagsgesellschaft.

Pasquier, R. (2009), Expertise on 'France/La réforme constitutionelle de 2003' for the Research Project 'Pat terns of Constitutional Reform Concerning Federal Structures', unpublished manuscript, Institute for Political Science at the Technische Universität Darmstadt.

Princen, S. (2007), Agenda setting in the European Union: A Theoretical Exploration and Agenda for Research, Journal of European Public Policy, Vol.14, No.1, pp.21 38.

Rawlings, R. (2003), Delineating Wales. Constitutional, Legal and Administrative Aspects of National Devo lution. Cardiff: University of Wales Press.

Russell, P. H. (2004), Constitutional Odyssey. Can Canadians Become a Sovereign People? Toronto: University of Toronto Press.

Sabatier, P. A. and Jenkins Smith, H. C. (1999), The Advocacy Coalition Framework: An Assessment, in P.A. Sabatier (ed.), Theories of the Policy Process. Boulder, CO: Westview Press.

Sartori, G. (1992), Demokratietheorie. Darmstadt: Wissenschaftliche Buchgesellschaft. 
Scharpf, F. W. (1997), Games Real Actors Play: Actor Centered Institutionalism in Policy Research. Boulder, CO: Westview Press.

Schultze, R. O. (2000), Constitutional Reform as Process, in R. O. Schultze and R. Sturm (eds), The Politics of Constitutional Reform in North America. Coping with New Challenges. Opladen: Leske+Budrich.

Scottish Constitutional Convention (1995), Towards Scotland's Parliament. Edinburgh: The Convention.

Secretary of State for Scotland (1997), Scotland's Parliament. Presented to Parliament by the Secretary of State for Scotland by Command of Her Majesty, July 1997. London: The Scottish Office.

Sinardet, D. (2010), Expertise on 'Belgium/Fifth State Reform (2000/01)' for the Research Project 'Patterns of Constitutional Reform Concerning Federal Structures', unpublished manuscript, Institute for Political Science at the Technische Universität Darmstadt.

Smith, J. (2002), Informal Constitutional Development: Change by Other Means, in H. Bakvis and G. Skog stad (eds), Canadian Federalism. Performance, Effectiveness, and Legitimacy. Toronto: Oxford Univer sity Press.

Stern, K. (1984), Das Staatsrecht der Bundesrepublik Deutschland Band I. München: C.H. Beck Verlag.

Trench, A. (2008), Finding a Voice for Wales. Assessing Three Phases of Constitutional Development in Wales. Paper presented at the, ECPR Joint Session of Workshops: Université de Rennes II.

Tsebelis, G. (2002), Veto Players. How Political Institutions Work. Princeton, NJ: Princeton University Press.

Vassallo, S. (2005), Le riforme costituzionali del centro destra, in C. Guarnieri and J. Newell (eds), Politica in Italia. Bologna: Il Mulino.

Vorländer, H. (1981), Verfassung und Konsensus. Berlin: Duncker \& Humblot.

Vorländer, H. (2006), Die Verfassung als symbolische Ordnung. Perspektiven einer kulturwissenschaftlich institutionalistischen Verfassungstheorie, in M. Becker and R. Zimmerling (eds), Politik und Recht. PVS Sonderheft 36. Wiesbaden: VS Verlag für Sozialwissenschaften.

Westerwelle, G. (2006), Rede von Dr. Guido Westerwelle zur Föderalismusreform I im Deutschen Bundes tag. Bundestag Stenographic Protocol 16/044. Berlin. 


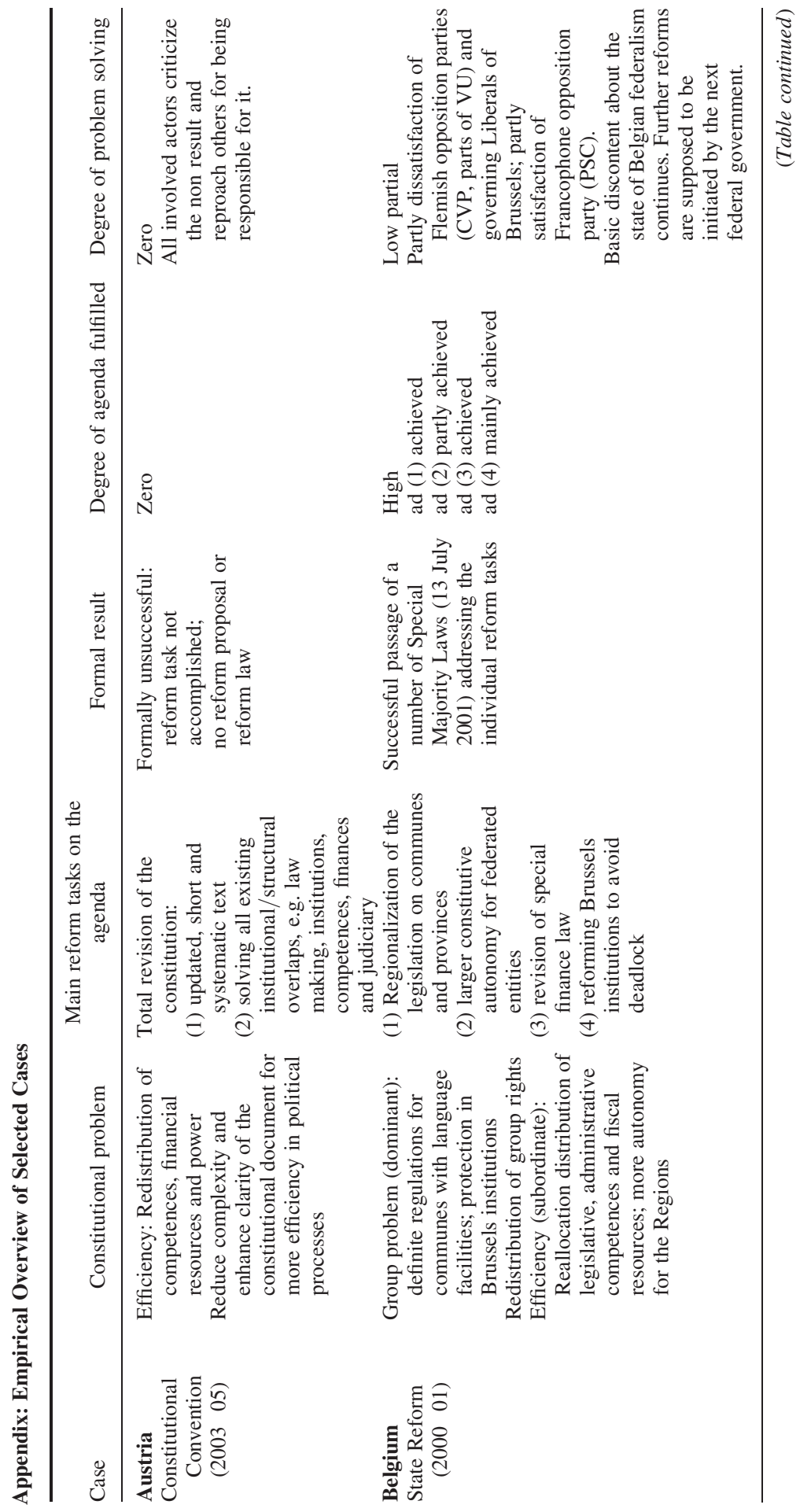


472

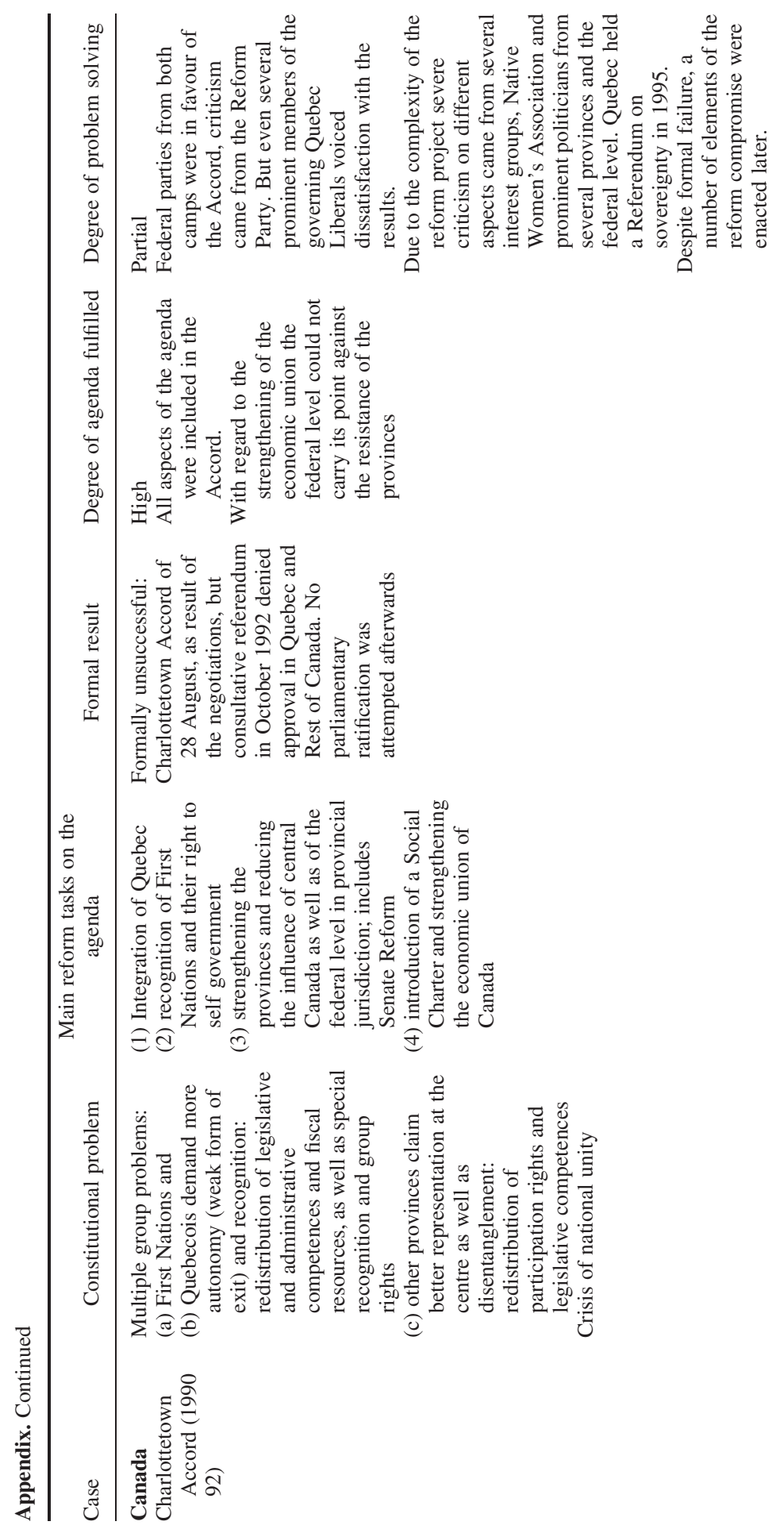



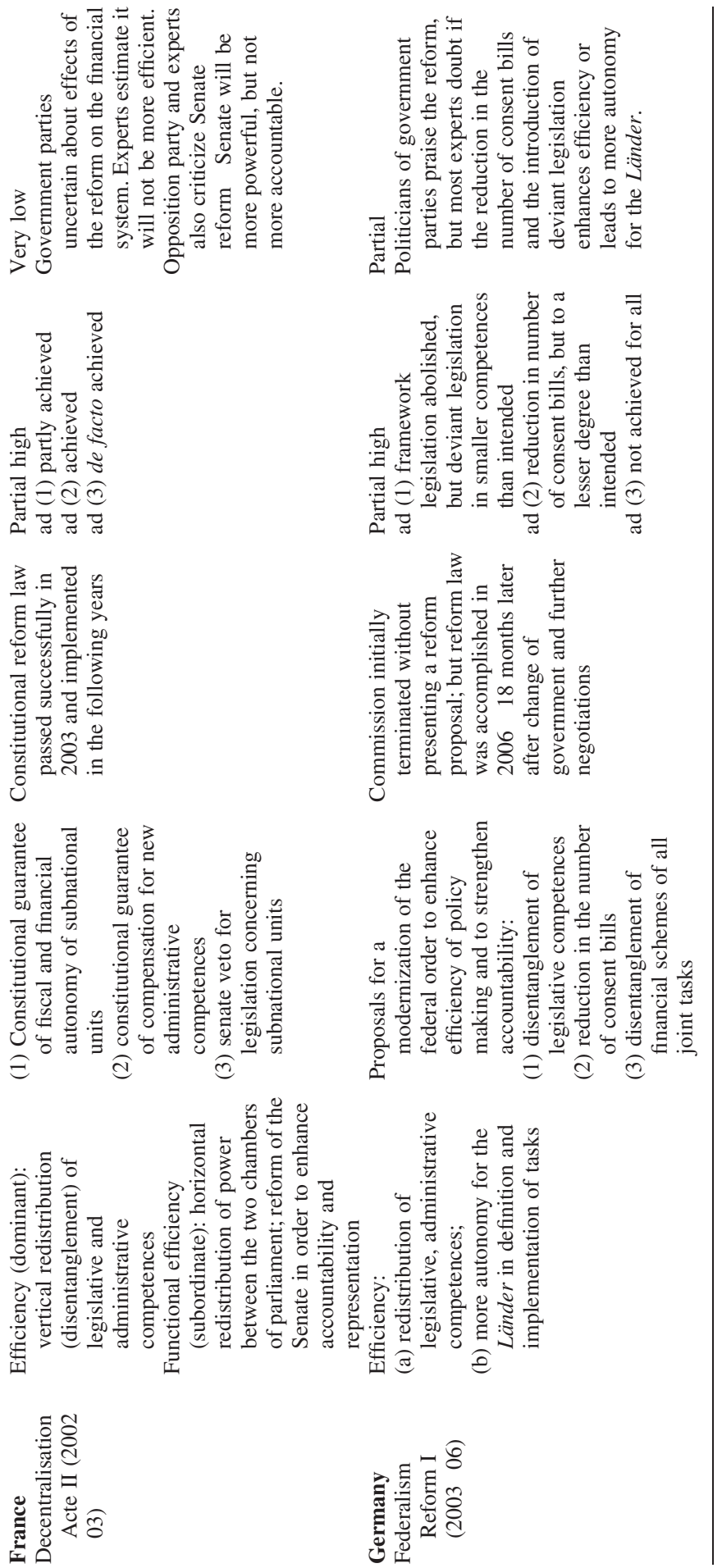


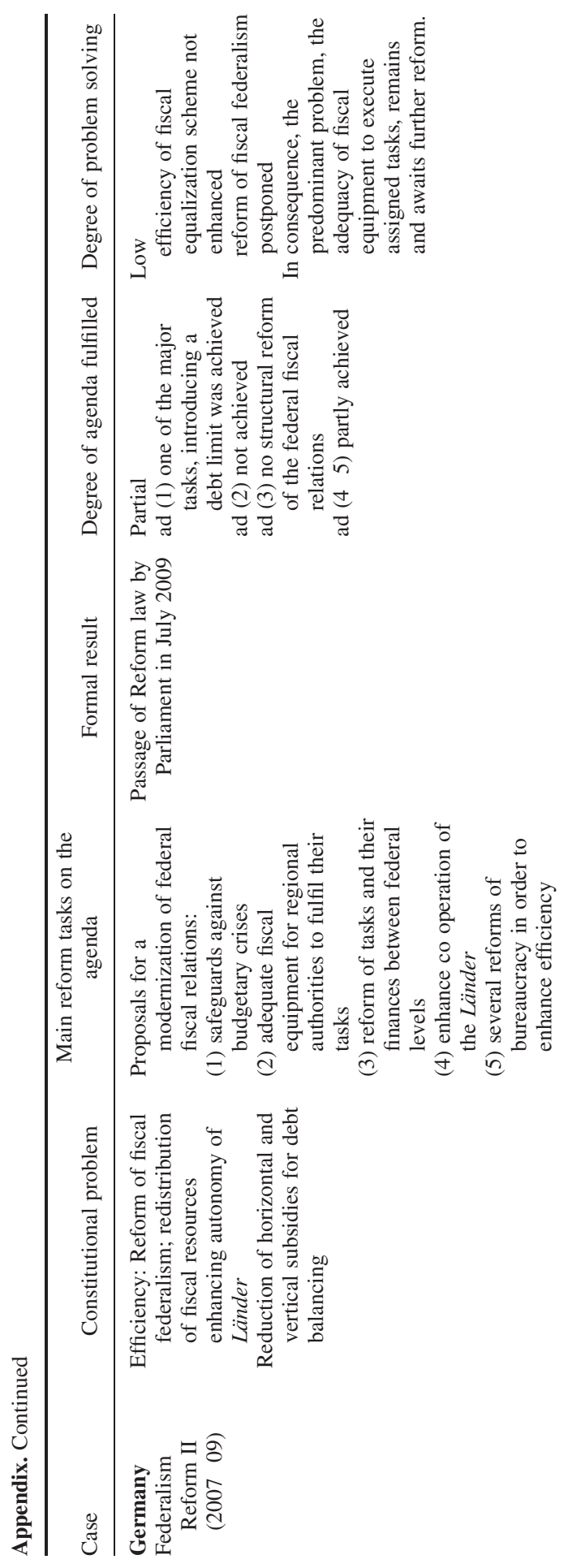



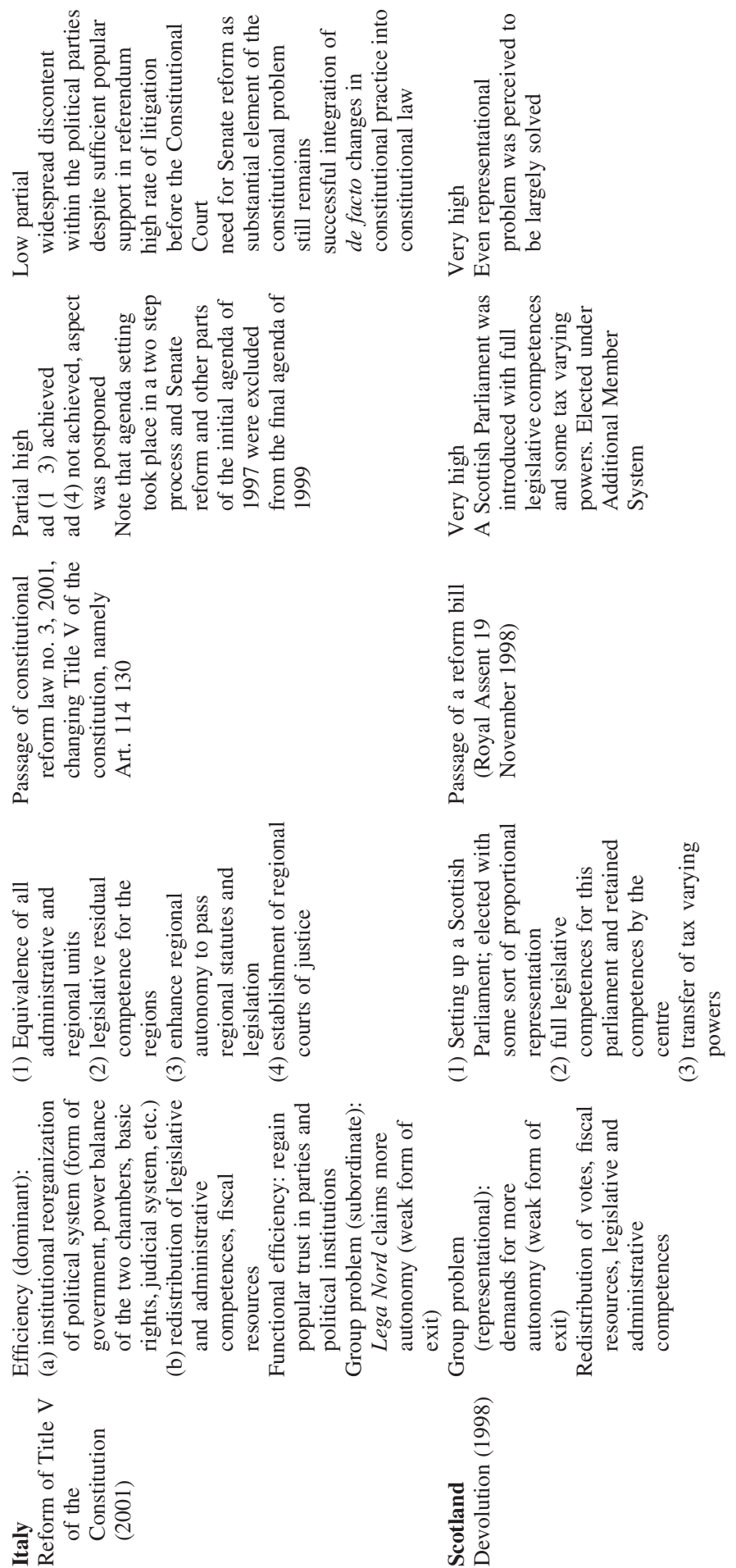


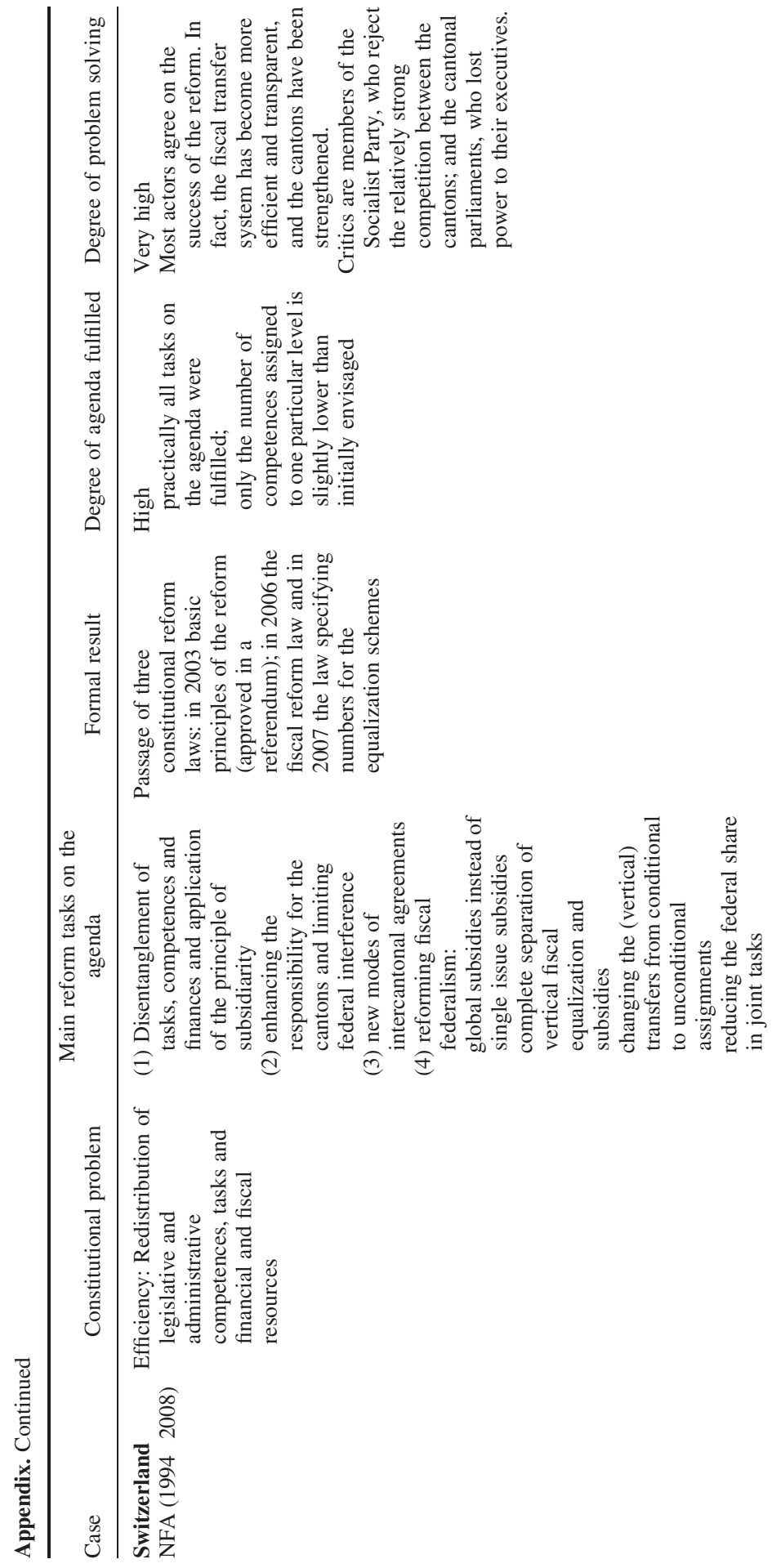




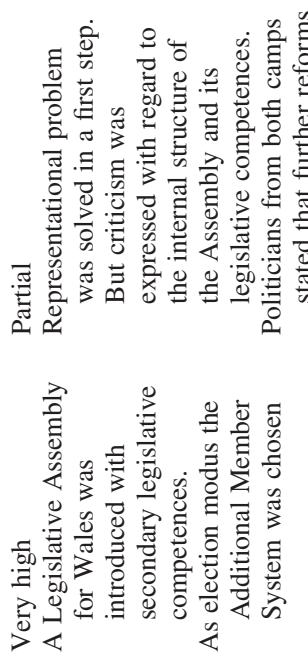

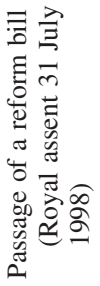
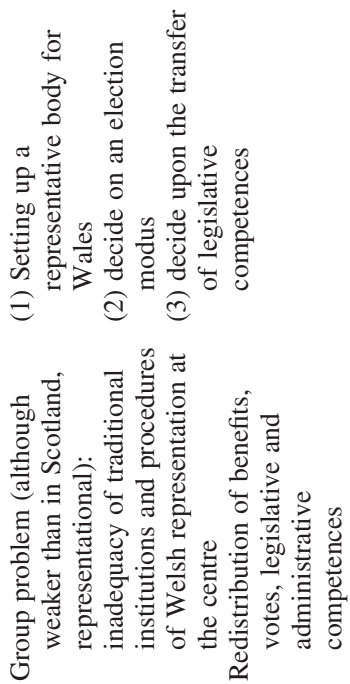

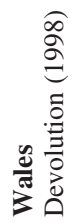

